\title{
The Narratives of Moral Panics in LGBT News Reporting
}

\author{
Triyono Lukmantoro \\ Communication Sciences, Faculty of Social dan Political Sciences \\ Diponegoro University \\ Semarang, Indonesia \\ (triyonolukmantoro@gmail.com)
}

\begin{abstract}
News media reporting for 20s January to end of February 2016 about Lesbian, Gay, Bisexual, and Transgender (LGBT) expressed narratives of moral panics. The headlines of LGBT issues stated that the sexuality group threatening social order. LGBT was positioned as the transgressor of social and religious norms. Media agenda also indicated that LGBT should be refused, although humanity reasoning applied in the case. Moreover, LGBT was regarded as the violator of human dignity. The claim makers, in the case, was ulama (the religious leaders), involved with the media to state that LGBT not only are mistakes on the social aspect but also sin before God. The state officials, finally, implicated by the media to legitimate policy that rejects LGBT existence.
\end{abstract}

Keywords-LGBT; moral panics; news media reporting; narratives

\section{INTRODUCTION}

The beginning was the straight news that contained the statement of Minister Research, Technology, and Higher Education Mohammad Nasir that LGBT is prohibited at the campus because it is campus as moral guardian. Besides that, the campus has values standard and moral standard that must be guarded. Minister Nasir also stated LGBT could destroy nation morality. Campus as the guard of nation morality should maintain the moral values and noble values. The statement $f$ Minister Nasir was the response for the existence of Support Group and Resource Center on Sexuality Studies (SGRC) in Indonesia University (Republika.co.id edition Saturday, 23 January 2016, 21:27)

The statement of Minister Nasir evoked many reactions. There are people agree with the minister. But, there was people criticized him. Controversies about LGBT become the heated debate because the dispute engendered the quarrel. Minister tried to muffle the dispute. In the press conference, Minister Nasir stated that he didn't prohibit LGBT activities at campus. In his opinion, association and assembly and activate institutional events are the rights for all citizen, including LGBT. The problem was not LGBT allowed or prohibited. The prohibition related to making love activities at campus. Even more, any group, LGBT or not, would be prohibited if they have sex at campus (Kompas.comeditionTuesday, 26 January 2016, 11:11). But, the Minister Nasir's explanation was useless.
The heated debate about LGBT spread beyond the campus walls.

Surely, the widespread of LGBT controversies as a result of media coverage. The heated issues of LGBT were reactions to SGRCin Indonesia University accused as LGBT advocate whereas the institution giving consult service to everybody that identifies themselves as LGBT. The media intentionally exploded LGBT issues because there are two important events that regarded as the relevant reference to society. First, the death of Akseyna Ahad Dori, a student of Indonesia University, on 26 March 2015. To this day, the death of Akseyna is still the mystery because the police can't reveal who killed him and what the motivation. Media haphazardly connect the death of Akseyna with LGBT community in the campus. Second, the death of Wayan Mirna Salihin aftermath she drank coffee mixed cyanide in a café in Jakarta. Jessica Kumala Wongso, victim's close friend, named as a suspect by the police. Once again, the media guessing the motive for murder is the lesbian jealousy to her couple that married with another man.

The perspective of media reporting in LGBT issues is harassing the sexual minority group. LGBT positioned as the dangerous profiles for the social living. Cultural value are so noble and highly respected be shattered because of LGBT presence. Media, finally, made LGBT as a pack of people and destructive social forces that inflict many tragic events, for example, the murder, happened in society. The media reporting in LGBT issues, by its telling stories techniques that can be read in the headlines, produce the narratives that reflecting moral panics.

The purpose of the paper is describing how journalism style applied by media in Indonesia indicated moral panics in reporting LGBT issues.

\section{THEORETICAL FRAMEWORKS}

When media positioned LGBT as the serious threat for Indonesia nation, the media involved and even became the important factor in engendering moral panics. Spiral effects that produced by the interaction of media, public opinion, the interest groups, and the authorities holders are the factors that produce moral panics [1]. Media, more than that, must be regarded as the important actor because media can create the public opinion. Media definitely determine the social groups 
that will be voiced loudly. Media, finally, intentionally implicated the authorities holder to amplify the full agenda of moral panics.

Moral panics can be regarded as ethical razzle when society embraces any social problem or groups that threaten the normal social order. Cohen stated that moral panics have characteristics: (1) there is a condition, episode, people or groups of people that defined as a threat to values and social interests; (2) the condition and the figures that threaten are represented by the media in specific style and stereotypes; (3) reactions to criticize, to resist, and more than is to eliminate arise in society, for example religious leaders, observers, politicians, or the conservative groups; (4) the later events in the moral panics are the presence of the people socially regarded as the experts that able to overcome the problem; (5) the experts made diagnosis and its solutions; and (6) the condition vanish, disappear, and can appear more visibly [2].

Goode and Ben-Yehuda propose five criteria to identify moral panics: First, the concern that presents widespread to influence behavior of a part or entire society. Second, hostility, in attitude and act, addressed to a group of people that threaten and destroy the social order. Third, the emergence of social consensus that regard there are the social groups that threaten the social living. Fourth, the disproportion that means any members of society that their behavior are questionable. Fifth, volatility is event that easy to appear and disappear [3].

LGBT has created moral panics in the context of patriarchal culture that uphold heteronormativity. Culture can be meant as "the ways of thinking, the ways of acting, and the material object that together form a people's way of life" [4]. Patriarchal culture places modes of thinking, modes of acting, and any material object that simultaneously privilege the male. Heteronormativity is the rules of patriarchy and heteronormativity as social norms. Any gender, sexualities, and sexual expressions outside of it as deviation [5]. LGBT is a category outside of normality of heteronormativity. Therefore, LGBT is placed as the deviant, conflict creator, and the abnormal.

Journalism that applied in the patriarchal culture and heteronormativity certainly disparage LGBT. In journalism prevails the iron law that every news came from the fact, but not every fact worthy to be news. Any fact that can fulfill criteria of news values such as impact, timeliness, proximity, conflict, currency, novelty, and relativity that suitable for being news [6]. LGBT is a social group that has worthy news values in the journalism. First, LGBT is a social group that has unusual characteristics, so LGBT placed as the extraordinary figure. And, second, LGBT is the unexpected group. Whenever LGBT reported by the media there are worthy news values for society. In relation to journalism and moral panics, it can be read at news media headlines. The Headlines can state the storytelling point of view and therefore all the outline of the entire story. Headlines direct the reader to follow certain types of narratives [7].

\section{ANALYSIS}

The following are the headline that disparage LGBT, such as: "LGBT The Serious Threat" (Republika edition of Sunday,
January 24, 2016), "Minister of Defense Considers LGBT as a Part of "Proxy War" that Must Be Watched" (Kompas.com edition of Tuesday, February 23, 2016, 22:08), "Board of Nahdlatul Ulama: LGBT Colliding with Religion and the Nature of Human Being" (Kompas.com edition of Friday, February 5, 2016, 14:24), Indonesian Broadcasting Commission Prohibits TV and Radio Promote LGBT (Kompas.com edition of Saturday, February 13, 2016, 08:06), "Minister of Women's Empowerment and Child Protection: I Reject LGBT Action, Supervise the Children!” (Kompas.com edition of Monday, February 15, 2016, 13:36 WIB), "Mayor of Tangerang Claims Instant Noodles Triggers LGBT" (Tribunjogja.com edition of Saturday, February 27, 2016, 20:13), "Indonesia Council of Ulama and Islamic Organizations: LGBT Haram" (Kompas.com edition of Wednesday, February 17 2016, 14:13), "Executive Board of Nahdlatul Ulama: LGBT Staining of Humanity (Antaranews.com edition of Thursday, February 25, 2016, 18: 51), "Prosperous Justice Party Politician: Government Need to Block LGBT Sites (Kompas.com edition f Tuesday, February 16, 2016, 06:56), "Regent Anas: LGBT Contagious but can be Cured (Kompas.com edition of Monday, February 22, 2016, 09: 41), "LGBT Disturb Religious Life (Republika.co.id edition of Friday, February 12, 2016, 14:26), "Coordinating Minister for Political, Legal, and Security Luhut Pandjaitan: LGBT Need Religious Enlightening" (Republika.co.id edition of Friday, February 12, 2016, 13: 03), and "Vice President Kalla Disagree with LGBT Campaign" (Kompas.com edition of Monday, February 15, 2016, 18:06).

To discuss the headlines, the Critcher's ideas [8] used as techniques of analysis. There are five guide questions, namely:

First, why and how some events interpreted by the news media as symbolizing a wider social problem? LGBT interpreted by the media as the group of people who threaten excellent social order. To refer this interpretation, there are "two key events" used by media to use justification to place LGBT as the actors that do the harmful behavior. The "two key events" are the tragic death of Akseyna Ahad Dori and Wayan Mirna Salihin. In fact, the media can't prove the "two key events" have relevance to LGBT. The media just operate assumptions with selected diction that humiliate LGBT.

Second, how are new social problems or issues labeled, defined and interpreted? LGBT has been labeled and stigmatized as the humans beyond limits out of social normality. There are labeling or naming to LGBT, such as the people who threaten the fabric of society, the unity destroyers, the transgressors of religious life, the violator of religious rules, the people who contradict with the human nature being, or the contagious disease. All the labeling has placed LGBT as the lost pack of people who deserve to be punished and excluded from the excellent social system. If they want to be excluded, LGBT should be cured.

Third, what kind of agenda is developed by news media and how does it become common across them? Media developed agenda that in any perspectives LGBT is the big mistake. In religious perspective, LGBT is the prohibited behavior. In the political perspective, LGBT is the form of war in the modern era that finally annihilate Indonesia nation. In 
social perspective, LGBT has become the serious threat to the children. The consequences are LGBT should be rejected even for humanitarian reasons.

Fourth, in what ways do the news media make use of claim makers or experts in its discussion of the problem? LGBT as the big problem discussed by the claim makers, namely religious leaders or ulama. That happened because it is the majority of Indonesian people are Moslems. The other religious leaders, that possibly refuse LGBT existence, never involved or interviewed in news reporting. Therefore, arose the words such as "LGBT haram" and "LGBT contrary to human nature (fitrah)". The dictions that explicitly reject LGBT existence can't be found in other religious nomenclature. Because of the religious leaders in intensive discussions, therefore the inferences are LGBT is not only the big mistake in humanitarian perspective, but also great sin before the God.

Fifth, how does the news media agenda gain support among influential political elites, sufficient to bring about policy changes? The influential political elites definitely involved with the media as the primary news source. They are the ministers interviewed to comment about LGBT. Even more, the ministers that out of away from the LGBT problems interviewed by the media, such as Coordinating Minister for Political, Legal, and Security and Minister of Defense. In the media perspective, LGBT is not only the sexuality issues, but also the political, legal, and even defense problems. Moreover, the Vice President also interviewed by the media just to legitimate that LGBT campaign should be prohibited. The officials state cohesively refuse LGBT existence with using more refined language than the religious leaders.

\section{CONCLUSION}

The media have expressed the narratives of moral panics in reporting LGBT issues for January 20s to the end of February
2016. The narratives revealed how media regarded LGBT as social actors that can disturb social order operating smoothly. Media stigmatized LGBT as the transgressors of religious, social, and nation norms. Media stated the agenda that LGBT should be refused definitely with any reasoning, including human rights, though. Media implicated the claim makers, in the case, was ulama as the religious leaders, to legitimate the views that LGBT is the mistake not only in humanitarian perspective but also in religious values. In the end, the ministers who are regarded as the profiles high positions as authorities holders involved with the media to convince the state to refuse LGBT although their language was softer than the ulama's speech.

\section{REFERENCES}

[1] Battle, Juan andColin Ashley. 2008. "Intersectionality, Heteronormativity, and Black Lesbian, Gay, Bisexual, and Transgender (LGBT) Families". In Black Women, Gender + Families, Vol. 2,No. 1 (Spring), pp. 1-24.

[2] Burns, Lynette Sheridan. 2002. Understanding Journalism. New Delhi: Sage Publications.

[3] Cohen, Stanley. 1972/2002. Folks Devils and Moral Panics: The Creation of the Mods and Rockers, 3rd Edition. London and New York: Routledge.

[4] Critcher, Chas. 2005. Mighty Dread: Journalism and Moral Panics. In Stuart Allan, ed., Journalism: University Press, pp. 177-187.

[5] Fulton, Helen. 2005. "Print News as Narrative". In Helen Fulton, et. al.Narrative and Media. Cambridge: Cambridge University Press, pp. 218-244.

[6] Goode, Erich and Nachman Ben-Yehuda. 2009. Moral Panics: The Social Construction of Deviance, 2nd Edition. Oxford: WileyBlackwell.

[7] Macionis, John J. 2012. Sociology: 14th Edition. Upper Saddle River: Pearson.

[8] Thompson, Kenneth.1998. Moral Panics. London and New York: Routledge. 